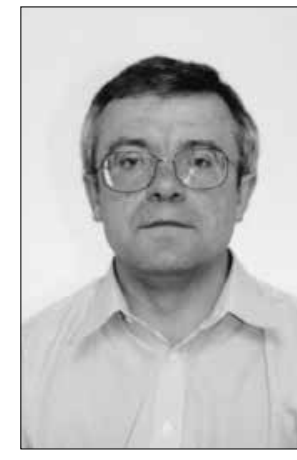

https://doi.org/10.24101/logos.2017.64

Gauta 20171020

VYTAUTAS RADŽVILAS

Vilniaus universitetas, Lietuva

Vilnius University, Lithuania

\title{
KELIOS PASTABOS POSTMODERNIOSIOS GLOBALIZACIJOS PRIEŠTARAVIMŲ KLAUSIMU
}

\author{
A Few Notes on the Issue of Internal Consistency \\ of Postmodern Gobalization
}

\begin{abstract}
SUMMARY
This paper is dedicated to the analysis of the evolution of the processes of globalization in the 21 st Century, and to the exploration of the internal consistency of globalism as it is composed of a group of ideologies that advocate the concept of globalization. The paper offers an argument that the process of globalization has contributed to the weakening and gradual disintegration of the three main forms of intersubjective communal life - society, nation and the nation state - which were the corner stones of the identity of individuals in the era of modernity. In addition, it is argued that globalization has contributed to the ongoing crisis of democracy. The expectation that the "Third Wave of Democratization" would establish liberal democracy as the dominant form of governance across the globe has proven itself to be unfounded in the wake of the crisis of democratic institutions that plagues the Western world. The paper aims to provide a coherent interpretation of the dynamics of globalization in the 21 st century, as well as to answer the question of whether the internal inconsistencies of postmodern globalization reveal its non-irreversible nature.
\end{abstract}

\section{SANTRAUKA}

Straipsnyje nagrinèjamos XXI a. postmoderniosios globalizacijos ir globalizmo plètros tendencijos bei prieštaravimai. Teigiama, kad gilèjant globalizacijai, silpnėja ir irsta moderniojo individo tapatumą laidavusios pagrindinès intersubjektyvios komunitarinio gyvenimo formos - visuomenè, tauta ir nacionalinè valstybè. Kartu didejja demokratijos krizè. XX a. pabaigoje puoselèti lūkesčiai, kad "trečioji demokratizacijos banga“ baigsis liberalios demokratijos įsitvirtinimu visame pasaulyje, ne tik neišsipildè, bet išryškèjo priešingos demokratijos nuosmukio ir minètos bangos nuoslūgio - tendencijos. Straipsnyje siekiama išsiaiškinti, kaip derėtų interpretuoti prieštaringą globalizacijos proceso dinamiką. Keliamas klausimas, ar vidiniai postmoderniosios globalizacijos prieštaravimai ir antinomijos neliudija, kad ji nebūtinai yra negrižtamas procesas.

RAKTAŽODŽIAI: demokratija, globalizacija, globalizmas, kosmopolitizmas, nacionalinis identitetas, nacionalinė valstybė. KEY WORDS: democracy, globalization, globalism, cosmopolitism, national identity, nation-state. 


\section{IŽANGA: GLOBALIZACIJA KAIP TEORINIS IR METODOLOGINIS TYRINĖJIMO IŠŠŪKIS}

Plačiai vartojama sąvoka "globalizacija" - itin neapibrèžta ir daugiareikšmè. Pamatinis dvilypumas ir prieštaringumas būdingas ir vadinamojo "globalizacijos proceso" aiškinimams bei vertinimams. Nesutariama net dèl to, kada šis procesas prasidejo ir kokie yra svarbiausieji jo skiriamieji bruožai. Globalizacijos problematikai skirtoje gausioje literatūroje nesunkiai įžvelgiamas plyšys tarp šio proceso "fenomenologijos" ir jo "esmès", t. y. gausūs empiriniai ìvairių jo aspektų aprašymai ir analizės tik menkai atskleidžia šio proceso prigimtį, varomąsias jejgas ir ilgalaikes jo sklaidos perspektyvas bei jo padarinius. Globalizacijos vyksmą lemiančios priežastys bei veiksniai aiškinami labai skirtingai, o jo vertinimo skalè apima platų spektrą požiūrių - nuo besąlygiškai optimistinių iki griežtai pesimistiniu (Held D., McGrew A., Goldblatt, Perraton J. 2002: 25-54).

Mejginant atskleisti globalizacijos proceso prigimti bei numatyti jo plètros tendencijas, būtina surasti nors kiek patikimus analizès ir vertinimo atskaitos taškus bei kriterijus. Svarbia tokio pobūdžio nuoroda laikytinos globalizacijos sąsajos su vadinamuoju modernizacijos projektu. Maža to, šiuolaikinè visuotinè globalizacija vertintina kaip ypatingas, itin radikalus šio projekto igyvendinimo tarpsnis. Šitoks globalizacijos apibūdinimas yra naudinga euristinè prielaida, atverianti galimybę taikyti tyrinèjimo strategija, leidžiančią globalizacijos vyksmą analizuoti ir vertinti dar platesnejje atskaitos sistemoje - istoriniame tradicijos ir moderno santykio kontekste.
Teorinè-metodologinè ir istorinè šio santykio analizè jam skirtuose darbuose iškyla kaip ",tradicionalizmo“ ir "modernizmo“ ginčas. "Tradicionalizmu“ ir „modernizmu“ čia vadinamos bendriausios vertybinès ir intelektualinès nuostatos tradicijos ir moderno atžvilgiu. Toks apibūdinimas leidžia atskirti jas nuo "konservatizmo" ir "radikalizmo" - pagrindiniu moderniuju ideologiniu srovių, ikūnijančiu refleksyviai konstruojamą individo santykị su Vakaru kultūros bei istorijos tradicija (Del Noce 2017: 35-67). Pirmąja gimstančios modernybès apraiška ir naujos epochos pradžia laikytinas sąmoningas Renesanso maištas prieš tradiciją (Lyotard 1993: 68). Jis sukūrè ir pačią tradicijos-moderno santykio problemą. Teorinę jos sklaidą lèmè iš pat pradžiu išryškëjęs naujưjų amžiu mąstymo paradigmos kultūrinis-istorinis daugiavektoriškumas bei prieštaringumas. Modernistu siekių simboliu tapo Švietimo projektas, ambicinga žmogaus visapusiško „išlaisvinimo“ programa (Kant 1996: 48-57), tradicionalistu - "grižimas i̇ Viduramžius“, arba restauraciniai užmojai atkurti ikimoderniąsias gyvenimo formas.

Katalikiškoji filosofija ilgai laikèsi atokiai nuo kylančios naujuju amžiu filosofijos, tad tradicijos ir moderno santykio klausimas pirmiausia tapo pastarojo ginču su savimi. Nuo Renesanso laiku moderną valdė "progresistinè" nuostata, kurios kulminacija tapo švietèjiškas optimizmas, tačiau protestantizme glūdèjęs pesimizmo grūdas taip pat sudygo. J.-J. Rousseau, F. Schillerio pa- 
sètos abejonès Švietimo projektu išsiliejo romantiniu sajūdžiu - pirmaja modernia reakcija prieš modernybę (Ruso 1979: 17-45; Schiller 1999: 38-49).

Šitaip keičiantis aplinkybėms, radikalus tradicionalizmas, kuriam daugiausia atstovavo kataliku mąstytojai, ir radikalus modernizmas, kurio ryškiausi atstovai buvo Švietimo ideologues, jau nebegalèjo būti vyraujančios nuostatos pamatiniu ginčo klausimu. I tradicijos ir moderno santykị ir tarpusavio priklausomybę pamažu pradèta žvelgti subtiliau.

Akivaizdžia šių poslinkių išraiška tapo konservatizmas ir radikalizmas - modernios ideologijos, ikūnijusios refleksyvų santyki su tradicija socialinio politinio mąstymo plotmejje. Daugelis XIX a. intelektualinės istorijos tyrinètojų yra pažymëję iš pažiūros keistą tokių pažangos šaukliu kaip A. Comte'as, K. Marxas, A. de Tocqueville' is ar E. Durkheimas konservatyvumą ir nostalgija praeičiai: ieškodami priimtino socialinès tvarkos modelio, šie mąstytojai žvalgési po antiką arba viduramžius (Nisbet 2000: 23-47).
Panašios permainos - „susitaikymas su modernybe" - vyko ir tradicionalistu stovykloje. Turbūt ryškiausia ju gaire tapo XIX a. paskutiniajame ketvirtyje prasidèjęs katalikiškosios filosofijos atnaujinimo sajū dis. Nuosaikiojo tradicionalizmo ir nuosaikiojo modernizmo pastangomis radikalių nuostatu ittaka menko. Tikejjimas, kad Vakaru modernizacijos vyksmas yra „istorinè klaida“ bei vis stipejantis dekadansas (Maritain 1925) ir jam lygiavertis įsitikinimas, kad priešrenesansinè Vakaru istorija yra tamsi priešistore ir "tuščio laiko" epocha, pamažu darèsi marginaliais Europos intelektualinio gyvenimo reiškiniais. Be to, abiejų nuosaikiujju nuostatu plètra padejo įsitvirtinti reflektyvios ir pliuralistinès tradicijos sampratai. Tebesitęsiančios tradicionalistų ir modernistų diskusijos ašis yra modernizacijos projekto ateities klausimas. Ginčydamiesi dèl šio projekto perspektyvu postmodernieji mąstytojai pakliūva i sūkuri dilemu, kurių šaltinis - virš postmoderno sklandantis taip galutinai ir "nedekonstruotos" tradicijos šešèlis.

\section{PAŽANGOS-ATŽANGOS DILEMA GLOBALIZACIJOS IR GLOBALIZMO SKIRTIES PERSPEKTYVOJE}

Pažangos-atžangos dilema persekioja ir svarstymus apie demokratijos perspektyvas šiuolaikiniame globalejjančiame pasaulyje. Viena vertus, praejusio šimtmečio pabaigoje kilusi demokratizacijos ,trečioji banga“" (Huntington 1991) lèmè jos plètrą i visus pasaulio regionus. Sparčiai mažèja skaičius valstybių, bent iš principo nepripažistančių demokratinès valdymo formos vertès ir neįsidiegusių formalių tokio valdymo mechanizmų bei procedū- rų. Šią masinę „,demokratizaciją“ kai kurie tyrinètojai vertina be išlygų optimistiškai, kaip artejjančio vakarietiškos demokratijos triumfo visame pasaulyje požymi bei pranašingą ženklą. Šitaip žvelgiant i demokratija jos plètros perspektyvos tiesiogiai siejamos su globalizacijos vyksmu ir teigiama, kad būtent globalizacija yra svarbiausias demokratizacijos procesą lemiantis veiksnys bei visiško ir galutinio demokratijos triumfo laidas. 
Tačiau egzistuoja ir griežtai kritiški globalizacijos bei demokratijos perspektyvų aiškinimai ir vertinimai. Šio požiūrio atstovai mano, kad tikètis vakarietiškos demokratijos modeli îsitvirtinant visame pasaulyje nèra pagrindo jau vien todèl, jog pačią Vakarų demokratiją yra ištikusi didelè krizè. Šiuo atveju pabrěžiama, kad Vakaru pasaulyje egzistuoja tik fasadinè demokratija, o kadaise iš tiesų buvęs liberaliosios demokratijos klestëjimo tarpsnis gali pasirodyti esąs tik gražus, tačiau trumpalaikis šio pasaulio istorijos epizodas (Unger 1976: 192-204; Rosanvalon 2004, 2008). Šiame kontekste plačiai analizuojami ir globalieji demokratiją griaunantys veiksniai. Pesimistinis požiūris i demokratijos ateiti šiuolaikinès globalizacijos sąlygomis pirmiausia grindžiamas teiginiais apie glaudžias modeniosios demokratijos ir nacionalinès valstybès sąsajas. Plètojant šiuos teiginius įrodinèjama, kad globalizacijos procesas pakerta kultūrines, ekonomines, socialines ir teisines nacionalinès valstybès egzistavimo sąlygas, kurios iš dalies yra ir pamatinès demokratijos egzistavimo bei išlikimo prielaidos (Manent 2008). Žvelgiant iš laiko nuotolio net sunku patikèti, kad vos prieš du dešimtmečius iškilūs demokratijos teoretikai galèjo nuoširdžiai tikèti šviesia demokratijos ",trečiosios bangos" ateitimi ir konstravo detalius ir ambicingus globalios kosmopolitinès demokratijos modelius, kurių utopiškumas šiandien yra akivaizdus ir nekelia jokių abejoniu (Held 1996: 335-360).

Mèginant nors iš dalies ivveikti globalizacijos ir demokratijos tyrinejjimus, it šešèlis persekiojančias, atrodytų, neišsprendžiamas pažintines ir vertybines antinomijas, tikslinga pabrèžti šiuolaikinès globalizacijos ir demokratizacijos procesus saistančią giją - šie procesai yra jau kelis šimtmečius realizuojamo ir plètojamo modernizacijos projekto aspektai. Dabartiniu metu jie skleidžiasi vis radikalesnèmis formomis. Ko gero, ne geriausiai matomi išoriniai globalizacijos bruožai, o jos pamate glūdintis vis spartèjantis ir radikalejantis modernizacijos, kaip tikrovès sampratos kaitos, vyksmas yra pagrindinis globalizacijos procesos bruožas, jo „esmë“. Jo radikalumas ir ypač ryškëjantis neprognozuojamas ir nevaldomas pobūdis daro įmanomą ir prasmingą "globalizacijos" ir "globalizmo" skirti. Globalizmas čia suprastinas kaip radikaliausia globalizacijos sklaidos bei raiškos forma, kurioje visiškai išryškejja modernizacijos projekto metafizinès ir socialinès prielaidos, jo vidinè logika, varomosios jègos bei potencialūs padariniai žmonijos ateičiai. Žvelgiant i i ši projektą per globalistinės perspektyvos prizmę aiškejja, kad jis yra kur kas daugiau negu paprastas socialinès inžinerijos eksperimentas. Jo esmè - antropologinè inžinerija, galinti paversti dar praeitame šimtmetyje skelbtą "žmogaus mirties" filosofiją tikrove. Viešai skelbiamas modernizacijos projekto tikslas - išlaisvinti žmogų, jo kūrybines galias iš juos kausčiusios tradicijos varžtų. Realus ir vis labiau ryškejjantis šio užmojo padarinys žmogaus formos sunaikinimas ir jo pavertimas demonišku niekiu. Akivaizdžiausias šių potencialiai pragaištingu užmojų patvirtinimas - ES architektų pastangos sukurti naują žmogaus tipą „,europieti“", kuris, net konstituciškai neigdamas savo krikščionškas šaknis, praran- 
da ir bet koki atpažistamą ir racionaliai apibrèžiamą tapatumą (Manent 2007; 2008). Šitoks „europietis“, kurio kontūrus, beje, vis dèlto i̇manoma įžvelgti, yra tokia pat "žmogaus" abstrakcija, koks buvo ir XX a. SSRS kurtas „,sovietinis žmogus“.
Tad globalizacijos ir globalizmo skirtis ne tik leidžia geriau užčiuopti globalizacijos proceso esmę, bet ir laikytina svarbia euristine nuoroda, padedančia adekvačiau analizuoti bei vertinti demokratijos raidos tendencijas šių dienų pasaulyje.

\section{KETURI ATRAMINIAI GLOBALIZACIJOS ANALIZE்S STULPAI}

Tyrinëjant įvairius šiuolaikinès globalizacijos aspektus, analizès atramos taškais laikytinos keturios pamatinès ir glaudžiai tarpusavyje susijusios sąvokos - individas, nacionaline valstybè, tauta, visuomene. Visos jos radosi kartu su modernybe ir yra moderno epochos teorinès savivokos karkasas ir branduolys. Vertinant teoriniu požiūriu, modernioji demokratijos samprata yra šiu pamatiniu sąvokų vedinys, o individo, nacionalinès valstybės, tautos ir visuomenės sampratos buvo pradejusio plačiai plisti bei isitvirtinti vakarietiško liberaliosios demokratijos modelio radimosi ir formavimosi sąlyga. Šiuolaikinėje postmodernaus mąstymo epochoje šiu pamatinių sąvokų turinys smarkiai pasikeitè, jos faktiškai yra "dekonstruotos", o vykstančio globalizacijos proceso sąlygomis išryškèjo jų, kaip sociopolitinės tikrovès darinių bei veiksnių, smukimo ir irimo požymiai. Todèl kaip niekad miglotos ir problemiškos tapo ir demokratijos išlikimo perspektyvos nepaisant jau minètos jos pasaulinès plètros tendencijos.

Apskritai individo atradimas arba veikiau „išradimas“ yra ne šiaip skiriamasis modernybės bruožas, bet tam tikra prasme ir visos pasaulio istorijos lūžio taškas. Būtent individas tapo jau kelis šimtmečius trunkančio ir toli gražu nepasibaigusio ir tik menkai suvokto metafizinio ir antropologinio vyksmo, paprastai vadinamo modernizacijos procesu, gelmine versme ir jo pagrindine varomąja jẻga. Kaip žinoma, moderniosios individo sampratos kūrëjais laikomi du Renesanso laikų mąstytojai: religinèje srityje individą atrado Martinas Lutheris, politineje - Niccolo Machiavelli (MacIntyre 2000: 117).

Individas yra žmogaus abstrakcija arba „žmogus be savybių" - šitaip glaustai galima nusakyti moderniosios individo sampratos esmę. Individo sąvoka yra abstrakti todèl, kad jos turinys atsaistomas nuo visų iprastinių žmonių savybių bei jų skirtumų. Tai reiškia, kad ši sąvoka tampa "tuščia“" ir numato abstrakčią individų lygybę, kuri gali būti suprantama tik kaip visiškas ju vienodumas. Todèl ši sąvoka, panašiai kaip moderniojo gamtos mokslo kuriamo fizikinio pasaulèvaizdžio atrama tapusi atomo sąvoka, tapo naujos žmogiškojo pasaulio ir jo tvarkos vizijos išeities tašku. Individo sąvoka dèl jos abstraktumo, arba tuštumo, neturi savarankiškos apibrèžties, tad savo esme yra „virtuali“ ir numato beribi negatyvios laisvès horizontą. Tad modernusis individas liaujasi buvęs 
žmogaus abstrakcija tik igydamas pozityvios laisvės jam suteikiamą apibrèžtumą, kuri, tariant Albrechto Wellmerio žodžiais, gali laiduoti tik intersubjektyvios komunitarinio gyvenimo formos (Wellmer, 1999), istoriškai išsiskleidusios tuo pačiu modernybès tarpsniu. Svarbiausios iš tokių formų ir buvo valstybė, tauta ir visuomenè. Taigi minètos - valstybès, tautos ir visuomenès - sąvokos yra tik individo sąvoką objektyvuojantys, tai yra iš jos kylantys ir ypatingu būdu ją realaus turinio ir prasmès pripildantys, konstruktai-vediniai.

Nacionalinė valstybè - modernybès laikotarpiu (nuo XV iki XVII a.) išsirutuliojęs naujas valdymo tipas, kurio svarbiausias bruožas - suverenumas. Tokios valstybès samprata neatsiejama nuo moderniosios individo sąvokos, o šio valdymo tipo sąsaja su lygybės idèja yra būtina moderniosios demokratijos sąlyga, jos tikroji ištaka ir versmè. Tik susiformavus moderniojo individo ir nacionalinès valstybės sampratoms galejo rastis naujo tipo, būtent "kiekybinè demokratija, iš principo besiskirianti nuo „kokybinès“, t. y. neegalitarinès ir visada turèjusios aristokratini matmeni, savo antikinès pirmtakès. Apskritai absoliučios, neribotai suverenios ir savo transcendentalinę prigimti realizuojančios bei skleidžiančios valstybès ir absoliutaus individo santykis yra visos moderniuju Vakaru politinès sanklodos pagrindas (Siedentop 2003: 99-112). Tačiau modernybės tarpsniu pamažu išsiskleidęs šiame santykyje glūdèjęs egalitarinès demokratijos potencialas $X X$ a. tapo ir totalitarinès demokratijos bei totalitarinio valdymo būdo gelmine versme.
Modernioji visuomenè - absoliutaus individo ir absoliučios valstybès sąveikos projekcinis vedinys - susiformavo kaip ypatinga „virtualaus“ viešumo sritis, kurios esminè savybè buvo „perspektyviškumas" - atvirumas vis naujoms sklaidos galimybėms (McIntyre 2000: 117-121). Tačiau iš pat pradžiu ji buvo paradoksalus ir trapus, dvilypès prigimties darinys. Viena vertus, ši visuomenè - naujaisiais amžiais atsiradusio refleksyvaus mąstymo produktas, perspektyvinis, t. y. nuolatos atnaujinamas socialinis projektas, kuris istoriškai skleidžiasi įvairiomis socialinès vaizduotès formomis (Taylor 2004). Kita vertus, ne mažiau svarbi jos perspektyviškumo prielaida buvo tradicija - šios visuomenès pagrindą sudariusio „individo“ absoliutaus unikalumo ir nelygstamos moralinès vertès transcendentinis, o vèliau transcendentalinis pagrindimas bei šios tradicijos sukauptas dvasiniu ir moralinių resursų rezervas, kurị laiką leidęs socializuojamam individui gana sèkmingai priešintis vis labiau ryškèjusiems totalizuojantiems moderniosios valstybès užmojams jo atžvilgiu.

Būtent šis dvilypis negatyvus ginties nuo valstybès prievartos ir pozityvus siejimosi su ja santykis brèžè gana griežtus ir apčiuopiamus visuomenès, kaip sąlygiškai nuo individo ir valstybès atskirtos bei savarankiškos viešojo gyvenimo srities, kontūrus ir padejo rastis skirtingoms teorinèms valstybès ir individo santykio sampratoms, kurias reprezentuoja liberalizmo, respublikonizmo ir komunitarizmo politinès filosofijos tradicijos (Ankersmit 1996: 7). 
Ši dideliu mastu tik tradicijos resursais sukurta ir palaikyta sąlygiška individo ir valstybės santykio pusiausvyra leido išsaugoti ir pilietinei visuomenei gyvybiškai svarbią privačios bei viešosios sričiu takoskyrą. Tačiau ši pusiausvyra pasirodè esanti trumpalaikè, ją tolydžio griovè pati moderno prigimtis. Nežabota socialumo sklaida, jau XIX a. viduryje vertusi individą tik socialiniu gyvūnu (Polanyi 2002: 119-123), ir šią sklaidą anksčiau pristabdžiusios tradicijos nykimas buvo bene du svarbiausi veiksniai, artinę postmodernios visuomenès kaip gryno socialumo būklę. Skiriamasis jos bruožas yra viešosios erdvès siaurëjimas ir viešojo žmogaus nykimas. Socializuodama individa, tradicija paradoksaliai $\mathrm{ji}$ saugojo nuo valstybès prievartos moralinio ir kultūrinio poveikio priemonèmis ribodama jo poreikių viešają raišką. Todèl tradicijos įtakos silpnėjimas tapo vienu svarbiausių veiksnių, lèmsių postmoder- nią slinkti grynojo socialumo link, kurią galima apibūdinti taip: nyksta ne tik privatumo ir viešumo, bet ir privatumo ir intymumo skirtis, o pats intymumas, išviešinamas ji tiesiogiai projektuojant $\mathfrak{i}$ politinio gyvenimo erdvę, tampa ypatinga totalizuojamo socialumo versme (Giddens 1991: 94-98). Todèl „post” būklëje randasi visos prielaidos daugelio autorių (H. Arendt, Z. Baumano, A. Giddenso) išpranašautai arba konstatuojamai itin pavojingai individo ir valstybės santykio inversijai: ankstesnę grèsmę, kad valstybė gali „panaikinti“ individa, pakeičia individo ir valstybès kitokio "susiliejimo" pavojus, kuriam tapus tikrove, valstybe ištirpsta individe ir tampa tik beribio jo troškimų lauko projekcija. Tokią "post" socialumo būklę, kai sparčiai nyksta pati pilietinè visuomenè (Seligman 2004: 145198), ko gero, iš tiesu galima apibūdinti F. Nietzsche's žodžiais pavadinant ją „paskutiniojo žmogaus“ epocha.

\section{MODERNIOSIOS TAUTOS DVILYPUMAS: KOSMOPOLITIZMO-NACIONALIZMO ANTINOMIJA}

Modernioji tauta nèra natūrali žmonių bendrija, kaip natūralumas buvo suprantamas iki modernybès laikų. Moderniosios europietiškos tautos ištaku reikia ieškoti jau Renesanso epochoje, laikotarpiu, kai prasidèjo pirmasis sukilimas prieš visą ankstesniajją kultūros ir tautinio gyvenimo tradiciją. Todèl tokia moderni tauta pirmiausia iškyla kaip „liaudis“ - refleksyviai konstruojamas ir palaikomas socialinis ir ideologinis darinys (Lyotard 1993: 76-78), arba, nusakant jos kilmę ir prigimti pasitelkus Be- nedicto Andersono apibūdinima, ji yra „isivaizduojama bendruomenè" (Anderson 1999). Politini apibrěžtumą ir stabilią formą jai suteikè tuo pat metu besiformavusi nacionalinė valstybè. Tačiau tradicinių „natūralių“ etnosų virsmas dirbtinėmis bendrijomis - moderniomis tautomis - buvo ilgas vyksmas. Kita vertus, dirbtinè modernios tautos prigimtis, jos buvimas įsivaizduojama bendrija lemia ir jos trapumą bei laikinumą. Kitaip tariant, moderni tauta kaip žmoniu organizacijos forma anksčiau ar vèliau turèjo 
būti „dekonstruota“ ir „peržengta“, nes pačioje jos, kaip dirbtinio konstrukto, prigimtyje, glūdi susinaikinimo pradas. Faktiškai šis jos dekonstravimo vyksmas prasidejjo dar XIX a., kai, pasak Arendt, mąstymą tautos kategorijomis pakeite vadinamasis rasinis mąstymas (Arendt 2001: 174-208), o galiausiai iš tautos sampratos išnyko paskutinieji jos „natūralios" prigimties likučiai. Mūsų dienomis vis akivaizdesnè nacionalinès valstybès erozija, kurią lemia daugybè globalių veiksnių, kartu yra ir ypatingo etnoso istorinio tipo - modernios tautos - krizès ženklas. Radikaliausieji (post)moderniojo kosmopolitizmo atstovai šaukliai šią krizę interpretuoja kaip „irodymą", kad modernioji tauta yra ateities neturinti ir todel privalanti kuo greičiau išnykti istorinė atgyvena. Tačiau neigiant tautą ir jos ateities perspektyvą patenkama $i$ dar vienos antinomijos spąstus. Modernujji nacionalizmą ir kosmopolitizmą sieja dialektinis abipusės priklausomybės ryšys, kurio nuolatinio buvimo net nereikia pagrindinèti rafinuotais teoriniais argumentais. Šis ryšys bent jau nuo XVIII a. pabaigos yra akivaizdus empirinis ir istorinis faktas. Juk modernusis kosmopolitizmas ir nacionalizmas faktiškai atsirado tuo pat metu, t. y. Apšvietos epochoje, ir nuo to laiko koegzistuoja ir palaiko vienas kitą tarsi, vaizdžiai kalbant, tos pačios monetos dvi pusès. Abiejų gyvybingumą palaiko juos saistantis dialektinio priešingumo ir itampos santykis. Viena vertus, tokie apie kosmopolitinę pasaulinę pilietiją svajoję Apšvietos mąstytojai kaip Immanuelis Kantas teigė universalios kosmopolitinès žmonijos idejją (Kant 1996: 27-47), kita vertus, tokie jo amžininkai kaip Gotfriedas Herderis ir jo sekèjai gynè tautų îvairovès ir nelygstamos vertès principą bei formulavo istoriškai besiskleidžiančios unikalios „,tautos dvasios" idejją (Herderis 1987). Kaip su tam tikra nuostaba XX a. konstatavo jau Isiahas Berlinas, ši idèja pasirodè esanti kur kas gyvybingesnè ir nesenstanti, nei manė kosmopolitizmo adeptai (Berlin 1995). Jos gyvybingumą paliudijo ir politine praktika. Žlugusioje Sovietų Sąjungoje keletą dešimtmečių trukusios pastangos praktiškai igyvendinti marksistinę-komunistinę „broliškų tarybinių tautų suartejimo ir susiliejimo" viziją buvo nesèkmingos - betautei „tarybinei liaudžiai" gimti taip ir nebuvo lemta. Su panašiais sunkumais susiduria ir Europos Sajungos vadovybès užmojis sukurti supranacionalini "paneuropini demosą“, arba ištautintą „naujujuc europiečių" liaudį. Net karščiausi šio projekto šalininkai faktiškai priversti pripažinti, kad šitoks projektas yra iš principo neigyvendinamas, nes pati „europinès tapatybès" sąvoka yra daugiareikšmè ir neapibrèžta, taigi ir vidujai prieštaringa, net grynai teorinio mąstymo plotmèje (Delanty 2002). Tai reiškia, kad „dekonstravus" nacionalizma, t. y. ji pavertus tik nupolitinta kultūrinio-etnografinio žaidimo forma, neišvengiamai tuo pat metu būtų „dekonstruota" bei savigriovos būdu žlugtų ir visus universalistinio globalizmo projektus grindžianti (post)moderniojo kosmopolitizmo ideja. 


\section{UŽSKLANDA: GLOBALI DEMOKRATIJA INDIVIDO VIRSMO DIVIDU PERSPEKTYVOJE}

Modernusis individas kaip unikalus modernybės išradimas yra naujo tipo refleksyviai konstruojamos tikrovès - absoliutus šaltinis ir vienintelis jos sklaidos atramos taškas. Toks individas gali būti suvokiamas tik kaip apofatiškai apibrèžiamas virtualus esinys, galintis objektyvuotis tik fenomeniškomis ir efemeriškomis „istorinès tikrovès" formomis. Valstybè, visuomenè ir tauta yra pagrindinès modernybès tarpsniu susiformavusios individo objektyvacijos formos.

Globalizacijos galimybè glūdi pačioje moderniojo individo sampratoje, kurios nuoseklus ir neišvengiamas vedinys yra kultūriškai ir politiškai unifikuoto pasaulio ideja ir globalistine politiškai suvienytos žmonijos vizija. Būtina šio projekto igyvendinimo sąlyga yra globali demokratija, kurios samprata grindžiama individų, kaip absoliučiai lygiu abstrakčių „,̌mogiškujjų esinių“, vienodumo ideja. Tokia demokratija jau nebegali būti suprantama tik kaip politinio valdymo forma. Ji tampa vis radikalèjančio modernizacijos proceso generuojamu globalių tikrovès transformacijų, tiksliau - šio vyksmo metu besirandančios naujos tikrovès formos moralinio ir politinio legitimavimo universalia prie-

\section{Literatūros sąrašas}

Anderson Benedict. 1999. Isivaizduojamos bendruomenés: apmastymai apie nacionalizmo kilme ir plitima. Iš anglų k. vertė A. Čižikienè. Vilnius: Baltos lankos.

Ankersmit Frank R. 1996. Aesthetic Politics. Political Philosophy beyond Fact and Value. Stanford: Stanford University Press. mone ir sąlyga. Tačiau, kaip rodo atlikta šio vyksmo analizè, refeleksyvaus globalizacijos proceso steigiama nauja tikrovè yra vidujai prieštaringa ir transgresyvi. Tai reiškia, kad gobaliacija yra, apibūdinant ją J. Schumpeterio vartotu ivvaizdžiu, beribis „,kūrybinès destrukcijos" vyksmas. Jos pletra dabartiniu postmoderniuoju tarpsniu dèl transgresyvaus šio vyksmo pobūdžio griauna visas moderniojo individo apibrèžtumą ir pastovumą laidavusias intersubjektyvias komunitarinio gyvenimo formas - visuomenę, tautą ir valstybę. Jų nyksmas lemia, kad yra "dekonstruojamas" ir pats individas kaip šiu formų šaltinis ir ištaka. Jis pats praranda apibrèžtą ir pastovu tapatumą virsdamas dividu arba skaidiniu - tik taku situacini ir kontekstinị tapatumą turinčiu efemerišku konstruktu. Tačiau atskleistas beribès postmoderniąą globalizaciją ikūnijančios principium individuationis sklaidos vidinis prieštaringumas duoda pagrindą kelti klausima, ar šitokia save pradedanti griauti globalizacija nepasiekè empiriniu ir loginiu savosios plètros ribu, taip pat suabejoti, ar bent jau dabartine savo forma ji iš tiesu yra negrižžtamas procesas.

Arendt Hannah. 2001. Totalitarizmo ištakos. Vilnius: Tyto alba.

Baumanas Zygmunt. 1998. Sociologinè postmodernumo teorija. Sociologija 2: 68-76.

Bauman Zygmunt. 2002. Globalizacija. Iš anglų k. vertè V. Rubavičius. Vilnius: Strofa.

Beck, Ulrich. 1997. The reinvention of politics: rethink- 
ing modernity in the global social order. Mark Ritter (transl.). Cambridge: Polity Press.

Berlin Isaiah. 1995. Nacionalizmas: praeityje nepaisytas, dabar - jèga, Vienove ir ivairové. Iš anglu k. vertè A. Jokubaitis. Vilnius: Amžius, p. 34-64.

Delanty Gerard. 2002. Models of European Identity: reconciling universalism and particularism, Perspectives on European politics and society. Leiden: Koninklijke Brill, NV, p. 345-359.

Del Noce Augusto. 2017. The Age of Secularization. Carlo Lancellotti (transl.). Montreal: McGillQueen's University Press.

Dürrschmidt Jörg, Taylor Graham. 2007. Globalization, modernity and social change: hotspots of transition. Basingstoke - New York: Palgrave Macmillan.

Foucault Michel. 2008. The Birth of Biopolitics. Lectures at the Collège de France, 1978-1979. Graham Burchell (transl.). Hampshire/New York: Palgrave MacMillan.

Gellner Ernest. 1996. Tautos ir nacionalizmas. Iš anglų k. vertè K. Rastenis. Vilnius: Pradai.

Giddens Anthony. 1991. Modernity and Self-Identity. Self and Society in the Late Modern Age. Stanford, Ca: Stanford University Press.

Held David. 1996. The Models of Democracy. Second edition. Cambridge: Polity Press.

Held David, McGrew Anthony, Goldblatt David, Perraton Jonathan. 2002. Globaliniai pokyčiai: politika, ekonomika ir kultūra. Vilnius: Margi raštai.

Herderis Johanas Gotfrydas. 1987. Idèjos žmonijos istorijos filosofijai. Filosofijos istorijos chrestomatija. Vilnius: Mintis, p. 398-428.

Huntington Samuel P. 1991. Democracy's Third Wave. Journal of Democracy. Spring, p. 12-34.

Kant Imanuel. 1996. Politiniai traktatai. Iš vokiečių k. vertė G. Žukas. Vilnius: Aidai.

Lyotard François. 1993. Postmodernus būvis. Iš prancūzų k. vertè M. Daškus. Vilnius: Baltos lankos.
Manent Pierre. 2007. What is a Nation? The Intercollegiate Revew - Fall, p. 23-31.

Manent Pierre. 2008. Demokratija be tautu. Apie savivaldos pabaiga Europoje. Vilnius: Versus aureus.

Maritain Jacques. 1925. Trois reformateurs. - Luther. Descartes. - Rousseau. Paris: Plon.

McIntyre Alasdaire. 2000. Trumpa etikos istorija. Dorovéss filosofijos istorija nuo Homero iki dvidešimto amžiaus. Iš anglų k. vertė I. Šeškauskienè. Vilnius: Charibdè.

Nisbet Robert A. 2000. Sociologijos tradicija. Iš anglų k. vertė D. Gudelis. Vilnius: Pradai.

Polanyi Karl. 2002. Didžioji transformacija: politinès ir ekonominés mūsu laiku ištakos. Iš anglų k. vertè J. Musteikytė ir R. Grikienis. Vilnius: Algarvè.

Rosanvallon Pierre. 2006. Democracy. Past and Future. Sammuel Moyn, ed. New York: Columbia University Press.

Rosanvallon Pierre. 2008. Counter-democracy: politics in an age of distrust. Arthur Goldhammer (transl.). Cambridge-New York: Cambridge University Press.

Ruso Žanas Žakas. 1979. Rinktiniai raštai. Iš prancūzų k. vertẻ L. A. Skūpas. Vilnius: Mintis.

Seligman Adam B. 1992. Pilietinès visuomenés ideja. Iš anglų k. vertė Auksė Mardosaitè. Vilnius: Lietuvos rašytojų sąjungos leidykla.

Schiller Friedrich. 1999. Laiškai apie estetini žmogaus ugdyma. Iš vokiečių k. vertė Antanas Gailius. Vilnius: Lietuvos rašytojų sajungos leidykla.

Siedentop Larry. 2003. Europos demokratija. Iš anglų k. vertè Leonas Tamas. Vilnius: Vaga.

Taylor Charles. 2004. Modern Social Imaginaries. Public Culture, p. 91-124.

Unger R. M. 1977. Law In Modern Society. London: The Free Press.

Welmer Albrecht. 1999. Freiheitsmodelle in der modernen Welt. Endspiele: Die unversöhnliche Moderne. Essays und Vorträge. Frankfurt am Mein: Suhrkamp. S. 15-53. 